\title{
Predictors of Gleason score upgrading in patients with prostate biopsy Gleason score $\leq 6$
}

\author{
Hasmet Sarici, MD; ${ }^{*}$ Onur Telli, MD; ${ }^{*}$ Orhan Yigitbasi, MD, ${ }^{\dagger}$ Musa Ekici, MD; ${ }^{\dagger}$ Berat Cem Ozgur, MD; \\ Cem Nedim Yuceturk, MD;* Muzaffer Eroglu, MD*
}

*Department of Urology, Ankara Training and Research Hospital, Ankara, Turkey; 'Department of Urology, Ankara Yildrrm Bayezit Training and Research Hospital, Ankara, Turkey

Cite as: Can Urol Assoc J 2014;8(5-6):e342-6. http://dx.doi.org/10.5489/cuaj.1499

Published online May 21, 2014.

\section{Abstract}

Introduction: The discrepancy between prostate biopsy and prostatectomy Gleason scores is common. We investigate the predictive value of prostate biopsy features for predicting Gleason score (GS) upgrading in patients with biopsy Gleason scores $\leq 6$ who underwent radical retropubic prostatectomy (RRP). Our aim was to determine predictors of GS upgrading and to offer guidance to clinicians in determining the therapeutic option.

Methods: We performed a retrospective study of patients who underwent RRP for clinically localized prostate cancer at 2 major centres between January 2007 and March 2013. All patients with either abnormal digital examination or elevated prostate-specific antigen at screening underwent transrectal ultrasound-guided prostate biopsy. Variables were evaluated among the patients with and without GS upgrading. Our study limitations include its retrospective design, the fact that all subjects were Turkish and the fact that we had a small sample size.

Results: In total, 321 men had GS $\leq 6$ on prostate biopsy. Of these, $190(59.2 \%)$ had GS $\leq 6$ concordance and 131 (40.8\%) had GS upgrading from $\leq 6$ on biopsy to 7 or higher at the time of the prostatectomy. Independent predictors of pathological upgrading were prostate volume $<40 \mathrm{cc}(p<0.001)$, maximum percent of cancer in any core $(p=0.011)$, and $>1$ core positive for cancer $(p<0.001)$. Conclusions: When obtaining an extended-core biopsy scheme, patients with small prostates $(\leq 40 \mathrm{cc})$, greater than 1 core positive for cancer, and an increased burden of cancer are associated with increased risk of GS upgrading. Patients with GS $\leq 6$ on biopsy with these pathological parameters should be carefully counselled on treatment decisions.

\section{Introduction}

With the widespread use of the prostate-specific antigen (PSA) screening test, the number of patients diagnosed with low-risk prostate cancer (LRPCa) has increased rapidly. Patients with clinical stage $\leq \mathrm{T} 2 \mathrm{a}$, biopsy Gleason sum $\leq 6$ and PSA $\leq 10 \mathrm{ng} / \mathrm{mL}$ are defined as low-risk prostate cancer by $\mathrm{D}^{\prime} \mathrm{Amico}$ and colleagues. ${ }^{1}$ Various treatment options, ranging from active surveillance to ablative therapies (i.e., radiation therapy, cryotherapy) to radical prostatectomy (RP), are currently avaliable for pat ients with low-risk prostate cancer. The choice of treatment is often based on the prostate biopsy Gleason score (GS). So an understanding of the features of the prostate biopsy allow us to better counsel prostate cancer patients during their treatment decision process.

Because GS upgrading at prostatectomy has been associated with poorer outcomes, the factors that affect the discrepancy between biopsy and prostatectomy GS must properly assessed. King and colleagues define clinically significant upgrading of the biopsy in 2 ways: (1) biopsy GS $\leq 6$ to prostatectomy GS $\geq 7$ and (2) biopsy GS $3+4$ to prostatectomy GS $4+3$ or higher. ${ }^{2}$ Although different biopsy methodologies were used, the upgrading rates of recent studies change from about $20 \%$ to $50 \% .^{3-7}$ We investigate the predictive value of prostate biospy features for predicting GS upgrading in patients with biopsy GS $\leq 6$ who underwent RP.

\section{Methods}

We performed a retrospective study of patients who underwent RP for clinically localized prostate cancer at 2 major research hospitals in Ankara, Turkey between January 2007 and March 2013. There were 442 patients who had biopsy and underwent RP. We excluded patients with missing data for biopsy GS, unknown RP GS status, pre-treatment PSA and patients with $<10$ cores sampled. We also excluded patients who had GS $\geq 7$ on biopsy. In the end, we included 321 patients. All patients with either abnormal digital examination or elevated PSA at screening underwent transrectal ultrasound (TRUS)-guided prostate biopsy by urologists at the 2 centres. The prostate was biopsied near the base, mid-gland, and apex, bilaterally, with 5 or 6 biopsies per side. Essentially, 10 to 12 baseline biopsy cores were obtained in all subjects, and additional biopsies were obta- 
ined to include suspicious appearing lesions if needed. RP was done by an open retropubic or laparoscopic approach. Prostate specimens after RP were step-sectioned at 3-mm intervals and entire specimens were examined as quarter mounts. GS, extraprostatic extension, seminal vesicle invasion and surgical margins were assessed according to a predefined template. A surgical margin was considered positive when prostate glands were present at the inked margin. Extracapsular extension was defined as tumour invasion into the periprostatic tissue. Pathological specimens were examined by experienced genitourinary pathologists. With approval from each institutional review board, we analyzed the clinical and pathological data.

The following initial diagnosis-related and prostatectomyrelated variables were collected: age, pre-biopsy PSA level, PSA density, prostate biopsy GS, prostate volume, number of positive biopsy cores, highest percentage of cancer in a biopsy core, mean core length, distribution of positive foci in biopsy specimen (in one lobe or both lobes), prostatectomy Gleason score, capsular invasion, margin status, extracapsular extension and seminal vesicle invasion. Because previous studies show a high correlation between TRUS volume and pathological prostate weight, we used pathological prostate weight as prostate volume. ${ }^{8,9}$ Patients were divided into groups according to age, PSA levels, PSA density, prostate weights, number of positive biopsy cores, highest percentage of cancer in a biopsy core and distribution of positive foci. These variables were evaluated in patients with and without GS upgrading. Continuous variables were compared using the Mann-Whitney test and categorical variables were compared using the Pearson chi square or Fisher exact test. Multivariate Cox proportional hazards analysis was performed to identify independent predictors of GS upgrading after RP. Multivariate logistic analysis of predictors of upgrading included patient age, preoperative PSA, prostate volume $<40 \mathrm{cc}$, number of cores positive for cancer, maximum percent of cancer in any core and time since surgery (days). A $p$ value of 0.05 was considered statistically significant. All statistical analyses were performed by SPSS software (SPSS Inc, Chicago, IL). The results are expressed as the mean \pm standard deviation $(\mathrm{SD})$.

\section{Results}

In total, 321 men were included in our study. Of these, 190 $(59.2 \%)$ patients had a GS $\leq 6$ on prostate biopsy and 131 $(40.8 \%)$ men had GS upgrading from GS $\leq 6$ on prostate biopsy to GS 7 or higher at RP (Table 1). The final GS was $3+4$ in $97(30.2 \%), 4+3(8.1 \%)$ in 26, and $8-9$ in 8 patients (2.5\%). The overall median follow-up time was 13.4 months (range: 0.3-43).

Patients of both groups were similar in age and preoperative PSA levels (Table 2). The upgraded group had signi-

\begin{tabular}{lc}
\hline $\begin{array}{l}\text { Table 1. Final radical prostatectomy specimens according } \\
\text { to Gleason scores }\end{array}$ \\
\hline Gleason score & No. patients \\
\hline $4(2+2)$ & 6 \\
$5(2+3$ or $3+2)$ & 20 \\
$6(3+3)$ & 164 \\
Upgrading & \\
$7(3+4)$ & 97 \\
$7(4+3)$ & 26 \\
$8(4+4)$ & 5 \\
$9(5+4)$ & 3 \\
Total & 321 \\
\hline
\end{tabular}

ficantly less than 40 cc $(21.6 \%$ vs. $53.4 \%)$ TRUS prostate volumes $(p<0.001)$ and higher PSA density $(0.20 \pm 0.15$ vs. $0.25 \pm 0.19$, respectively, $p=0.003)$. More patients in the upgraded group had more than 1 positive core $(73.3 \%$ vs. $25.3 \% ; p<0.001)$ and a maximum percent of cancer in any core $(41 \pm 29$ vs. $28 \pm 22 ; p<0.001)$ than in the non-upgraded group.

In the multivariate logistic regression analysis, prostate volume $<40 \mathrm{cc}(p<0.001)$, maximum percent of cancer in any core $(p=0.011)$, and $>1$ core positive for cancer $(p<0.001)$ were independent predictors of pathological upgrading. In our study, age, PSA and time since surgery failed to predict GS upgrading (Table 3).

We compared the pathologic outcome at RP between the GP non-upgraded group and the upgraded group (Table 4). Pathological adverse outcomes, such as capsular invasion, extracapsular extension, seminal vesicle invasion and positive surgical margins, were associated with GS $\leq 6$ biopsy patients who were upgraded postopereratively.

\section{Discussion}

Although many factors are taken into consideration to determine treatment, managing prostate cancer patients is often based on the biopsy GS. It has been well-documented that the prostatectomy GS differs from biopsy GS. ${ }^{10-12} \mathrm{D}^{\prime} \mathrm{Amico}$ and colleagues found that about $40 \%$ of men with GS $\leq 6$ at biopsy had high-grade disease at prostatectomy. ${ }^{13}$ Therefore, the discrepancy between biopsy and prostatectomy GS must be properly assessed and understood. We determine the predictors of GS upgrading and offer guidance to clinicians in determining the best therapeutic option for their patients.

Considering the equal proportion of high-grade disease across all prostate tissue and the equal numbers of biopsy cores taken, the detection of high-grade disease is decreased in larger prostates. Therefore, larger glands would likely be upgraded because smaller tissue would be evaluated. In early studies, researchers have described a sampling artifact or detection bias in larger prostates and these may 
Sarici et al.

\begin{tabular}{|c|c|c|c|}
\hline & Gleason score $\leq 6$ & Gleason score $\geq 7$ & $p$ value \\
\hline No. patients & 190 & 131 & \\
\hline Age at diagnosis, mean \pm SD & $65.27 \pm 5.85$ & $66.13 \pm 7.11$ & \\
\hline No. $<60$ & 43 & 32 & 0.214 \\
\hline No. $>60$ & 147 & 99 & \\
\hline $\mathrm{tPSA}(\mathrm{ng} / \mathrm{mL})$ mean $\pm \mathrm{SD}$ & $10.07 \pm 6.68$ & $10.45 \pm 7.75$ & 0.971 \\
\hline $\begin{array}{l}\text { TRUS volume }(\mathrm{cc}) \\
\leq 40 \\
41-60 \\
>60\end{array}$ & $\begin{array}{l}41(21.6 \%) \\
84(44.2 \%) \\
65(64.2 \%)\end{array}$ & $\begin{array}{c}70(53.4 \%) \\
48(36.6 \%) \\
13(9.9 \%)\end{array}$ & $<0.001$ \\
\hline $\begin{array}{l}\text { PSA density }(\mathrm{ng} / \mathrm{mL} / \mathrm{cc}) \pm \mathrm{SD} \\
\text { Mean (range) }\end{array}$ & $\begin{array}{c}0.20 \pm 0.15 \\
{[0.17(0.02-.03)]}\end{array}$ & $\begin{array}{c}0.25 \pm 0.19 \\
{[0.20(0.05-0.27)]}\end{array}$ & 0.003 \\
\hline $\begin{array}{l}\text { No. positive cores for cancer } \\
1 \text { core } \\
>1 \text { core }\end{array}$ & $\begin{array}{l}142(74.7 \%) \\
48(25.3 \%)\end{array}$ & $\begin{array}{l}35(26.7 \%) \\
96(73.3 \%)\end{array}$ & $<0.001$ \\
\hline Maximum $\%$ cancer in any core \pm SD & $28 \pm 22(20)$ & $41 \pm 29$ & $<0.001$ \\
\hline $\begin{array}{l}\text { Biopsy core length }(\mathrm{mm}) \pm \mathrm{SD} \\
\text { Mean (range) }\end{array}$ & $\begin{array}{c}11.34 \pm 1.66 \\
{[11(7.6-18.41)]}\end{array}$ & $\begin{array}{c}11.11 \pm 1.33 \\
{[10.9(8.2-15.2)]}\end{array}$ & 0.277 \\
\hline $\begin{array}{l}\text { Time since surgery (days) } \pm \text { SD } \\
\text { Mean (range) }\end{array}$ & $\begin{array}{l}47.26 \pm 18.31 \\
{[45(20-124)]}\end{array}$ & $\begin{array}{c}52.05 \pm 22.59 \\
{[45(20-110)]}\end{array}$ & $<0.001$ \\
\hline
\end{tabular}

tPSA: total prostate-specific antigen; TRUS: transrectal ultrasound; PSA: prostate-specific antigen; SD: standard deviation.

have led to GS upgrading in larger prostates. ${ }^{14,15}$ An explanation for missing high-grade cancer on biopsy would be biopsy under-sampling (sextant core biopsy) of the prostate. However, recent data, which used extended biopsy schemes to evaluate the effect of prostate volume on GS upgrading, have suggested the reverse - smaller glands are more likely to be upgraded. $4,7,9,16,17$ Our results also confirm the inverse relationship between volume and GS upgrading. We suggest that, when the extended core biopsy was taken, smaller prostates significantly were more likely to be upgraded. This may be related with lower androgenicity or lower levels of growth factors, such as insulin-like growth factor that can affect prostate cancer growth and differentiation..$^{9,18-20}$ Supporting this theory, Freedland and colleagues found that patients with prostate cancer with smaller glands have more high-grade and aggressive disease. ${ }^{18}$ Men with a larger prostate have a higher PSA level, leading to an earlier biopsy for diagnosis of prostate cancer, so low-grade cancer can be detected earlier. This theory can also explain that larger prostates are less likely to be upgraded. However, these

\begin{tabular}{|c|c|c|c|}
\hline Variable & OR & $95 \% \mathrm{Cl}$ & $p$ value \\
\hline Age & 1.004 & $0.968-1.036$ & 0.756 \\
\hline PSA & 1,097 & $0.982-1.118$ & 0.056 \\
\hline Prostate volume $<40 \mathrm{cc}$ & 5.669 & $2.235-12.965$ & $<0.001$ \\
\hline Maximum \% cancer in any core & 2.324 & $1.038-3.228$ & 0.009 \\
\hline More than 1 core for cancer & 5.772 & $3.416-10.942$ & $<0.001$ \\
\hline Time since surgery (days) \pm SD & 2.065 & $0.978-4.116$ & 0.054 \\
\hline
\end{tabular}

hypotheses have not yet been fully elucidated.

The effect of PSA levels on GS upgrading has been examined; however, only a few studies have investigated the effect of PSA density on the risk of GS upgrading. In our study, we found that the frequency of upgrading was higher in the elevated PSA density group. Kundu and colleagues found that patients with higher PSA density had more aggressive clinically localized prostate cancer. ${ }^{21}$ Also, Freedland and colleagues found that higher PSA density levels were associated with higher grade disease. ${ }^{22}$ This finding also can be helpful in understand the association between smaller prostates and higher GS upgrading. In similar PSA serum levels, smaller prostates have higher PSA density levels and would therefore have high-grade cancer.

Tumour burden is also another risk factor for GS upgrading. Although their study is limited by a small patient population, Dong and colleagues found that $>1$ biopsy core or greater than $10 \%$ of any positive cores for prostate cancer may be predict upgrading. ${ }^{7}$ Similarly Serkin and colleagues found that patients with an increased burden of cancer on biopsy are likely to be upgraded. ${ }^{16}$ We found that the num-

Table 4. Pathological characteristics of patients with Gleason score $\leq 6$ cancers at biopsy in non-upgraded and upgraded groups

\begin{tabular}{lccc}
\hline Variable & $\begin{array}{c}\text { Gleason } \\
\text { score } \leq 6\end{array}$ & $\begin{array}{c}\text { Gleason } \\
\text { score } \geq 7\end{array}$ & p value \\
\hline Capsular invasion (RRP) & $39(20.5 \%)$ & $82(62.6 \%)$ & $<0.001$ \\
Extracapsular extension & $12(6.3 \%)$ & $26(19.8 \%)$ & $<0.001$ \\
Seminal vesicle invasion & $3(1.6 \%)$ & $8(6.1 \%)$ & 0.056 \\
Positive margin status & $20(10.5 \%)$ & $45(34.4 \%)$ & $<0.001$ \\
\hline RRP: radical retropubic prostatectomy. & & & \\
\hline
\end{tabular}


ber of positive cores and the highest percentage of cancer involvement of any core on biopsy are also important predictor factors of GS upgrading risk. Specifically, patients with $>1$ positive core are 5.982 times more likely to have GS upgrading.

When we analyzed the patients who were upgraded, we found that the occurrence of capsular invasion, extraprostatic extension, positive surgical margin and seminal vesicle invasion were all significantly increased. We know that patients with these parameters at prostatectomy have poorer outcomes, such as earlier biochemical recurrence, shorter disease-free survival and decreased time to initiation of hormone therapy.

Some studies have evaluated the effect of age on biopsy accuracy. Richstone and colleagues conducted the first major study on this subject. They found that the frequency of upgrading was higher in older patients ( $\geq 70$ years), but this was not significant on multivariate analysis. Their study found that patients aged $\geq 70$ years are more likely to be upstaged after RP. ${ }^{23}$ In another study, Bright and colleagues found no association between age and GS upgrading. ${ }^{24}$ In contrast, in a study of 1836 patients, Gershman and colleagues found an association between older age and GS upgrading. ${ }^{25}$ Our study shows that age was not a predicting factor of GS upgrading.

Our study has its limitations. Firstly, this study introduces inherent bias due to its retrospective design. Secondly, although it includes pathological data from 2 centres for 6 years, all biopsy and prostatectomy specimens were evaluated with the same Gleason grading criteria by experienced genitourinary pathologists. Thirdly, because previous studies show a high correlation between TRUS volume and pathological prostate weight, we used pathological weight as a surrogate of TRUS volume. Also, our subjects were Turkish natives, so our results may be different with other nationalities. Finally, we evaluated patients with biopsy GS $\leq 6$ who underwent RP; therefore we did not risk attaining an upgrading due to higher grade disease on biopsy. Notwithstanding these limitations, our study is important because it is the first of its kind coming from Turkey.

\section{Conclusion}

When obtaining an extended-core biopsy scheme, we found that patients with small prostates ( $\leq 40 \mathrm{cc}$ ), with $>1$ positive core for cancer and with an increased burden of cancer in prostate biopsy have a higher risk of GS upgrading. Also, patients with GS upgrading at prostatectomy tend to have poorer outcomes. Therefore, our results have clinical implications for risk-stratification and treatment choice, especially in choosing of non-surgical treatment options, such as active surveillance and watchful waiting, for patients with GS $\leq 6$ on biopsy.
Competıng ınterests: Dr. Sarici, Dr. Telli, Dr. Yigitbasi, Dr. Ekici, Dr. Ozgur, Dr. Yuceturk and Dr. Eroglu all declare no competing financial or personal interests.

This paper has been peer-reviewed.

\section{References}

1. D'Amico AV, Whittington R, Malkowicz SB, et al. Biochemical outcome after radical prostatectomy, external beam radiation therapy or interstitial radiation therapy for clinically localized prostate cancer. JAMA 1998;280:969-74. http://dx.doi.org/10.1001/jama.280.11.969

2. King CR, McNeal JE, Gill H, et al. Extended prostate biopsy scheme improves reliability of Gleason grading: Implications for radiotherapy patients. Int I Radiat Oncol Biol Phys 2004;59:386-91. http://dx.doi. org/10.1016/i.i.irobp.2003.10.014

3. Gofrit ON, Zorn KC, Taxy JB, et al. Predicting the risk of patients with biopsy Gleason score 6 to harbor a higher grade cancer. J Urol 2007;178:1925-8. http://dx.doi.org/10.1016/i.juro.2007.07.049

4. Turley RS, Hamilton RJ, Terris MK, et al. Small transrectal ultrasound volume predicts clinically significant Gleason score upgrading after radical prostatectomy: Results from the SEARCH database. J Urol 2008;179:523-7. http://dx.doi.org/10.1016/i.juro.2007.09.078

5. Kulkarni GS, Lockwood G. Evans A, et al. Clinical predictors of Gleason score upgrading: Implications for patients considering watchful waiting, active surveillance or brachytherapy. Cancer 2007;109:2432-8. http://dx.doi.org/10.1002/cncr.22712

6. Hong SK, Han BK, Lee ST, et al. Prediction of Gleason score upgrading in low-risk prostate cancers diagnosed via multi ( $\geq 12$ )-core prostate biopsy. World J Urol 2009;27:271-6. http://dx.doi.org/10.1007/ s00345-008-0343-3

7. Dong F, Jones IS, Stephenson AJ, et al. Prostate cancer volume at biopsy predicts clinically significant upgrading. J Urol 2008; 179:896-900.

8. Sajadi KP, Terris MK, Hamilton RJ, et al. Body mass index, prostate weight and transrectal ultrasound prostate volume accuracy. J Urol 2007; 178:990-5. hittp://dx.doi.org/10.1016/i.juro.2007.05.049

9. Turley RS, Terris MK, Kane CJ, et al. The association between prostate size and Gleason score upgrading depends on the number of biopsy cores obtained: Results from the Shared Equal Access Regional Cancer Hospital Database. BJU Int 2008;102:1074-9. http://dx.doi.org/10.1111/i.1464410X.2008.08015.x

10. Gregori A, Vieweg J, Dahm P, et al. Comparison of ultrasound-guided biopsies and prostatectomy specimens: Predictive accuracy of Gleason score and tumor site. Urol Int 2001;66:66-71. http://dx.doi. org/10.1159/000056573

11. Swed PD, Gomez P, Manoharan M, et al. Limitations of biopsy Gleason grade: Implications for counseling patients with biopsy Gleason score 6 prostate cancer. J Urol 2004;172:98-102. http://dx.doi. org/10.1097/01.ju.0000132135.18093.d6

12. Freedland SJ, Kane CJ, Amling CL, et al. Upgrading and downgrading of prostate needle biopsy specimens: Risk factors and clinical implications. Urology 2007;69:495-9. http://dx.doi.org/10.1016/i. urology.2006.10.036

13. D'Amico AV, Renshaw AA, Arsenault L, et al. Clinical predictors of upgrading to Gleason grade 4 or 5 disease at radical prostatectomy: Potential implications for patient selection for radiation and androgen suppression therapy. Int J Radiat Oncol Biol Phys 1999;45:841. http://dx.doi.org/10.1016/S03603016(99)00260-6

14. Uzzo RG, Wei JT, Wauldbaum RS, et al. The influence of prostate size on cancer detection. Urol 1995;46:831-6. http://dx.doi.org/10.1016/S0090-4295(99)80353-7

15. Kulkarni GS, Al-Azab R, Lockwood $G$, et al. Evidence for a biopsy derived grade artifact among larger prostate glands. J Urol 2006;175:505-9. http://dx.doi.org/10.1016/S0022-5347(05)00236-3

16. Serkin FB, Soderdahl DW, Cullen J, et al. Patient risk stratification using Gleason score concordance and upgrading among men with prostate biopsy Gleason score 6 or 7. Urol Oncol 2010;28:302-7. http:// dx.doi.org/10.1016/i.urolonc.2008.09.030

17. Davies JD, Aghazadeh MA, Phillips $S$, et al. Prostate size as a predictor of Gleason score upgrading in patients with low risk prostate cancer. J Urol 2011;186:2221-7. http://dx.doi.org/10.1016/i. juro.2011.07.104

18. Freedland SJ, Isaacs WB, Platz EA, et al. Prostate size and risk of high-grade, advanced prostate cancer and biochemical progression after radical prostatectomy: A search database study. J Clin Oncol 2005;23:754654. http://dx.doi.org/10.1200/JC0.2005.05.025

19. Hammarsten J, Högstedt B. Hyperinsulinaemia: A prospective risk factor for lethal clinical prostate cancer. Eur J Cancer 2005;41:2887-95. http://dx.doi.org/10.1016/i.ejca.2005.09.003 
Sarici et al.

20. Partin AW, Oesterling JE, Epstein JI, et al. Influence of age and endocrine factors on the volume of benign prostatic hyperplasia. J Urol 1991;145:405-9.

21. Kundu SD, Roehl KA, Yu X, et al. Prostate specific antigen density correlates with features of prostate cancer aggressiveness. J Urol 2007;177:505-9. http://dx.doi.org/10.1016/i.juro.2006.09.039

22. Freedland SJ, Amling CL, Dorey F, et al. Race as an outcome predictor after radical prostatectomy: Results from the Shared Equal Access Regional Cancer Hospital (SEARCH) database. Urology 2002;60:670-4 http://dx.doi.org/10.1016/S0090-4295(02)01847-2

23. Richstone L, Bianco FJ, Shah HH, et al. Radical prostatectomy in men aged $\geq 70$ years: Effect of age on upgrading, upstaging and the accuracy of a preoperative nomogram. BJU Int 2008;101:541-6. http:// dx.doi.org/10.1111/j.1464-410X.2007.07410.x
24. Bright E, Manuel C, Goddard IC, et al. Incidence and variables predicting Gleason score upgrading between transrectal ultrasound-guided prostate biopsies and radical prostatectomy. Urol Int 2010;84:180-4. httrp:// dx.doi.org/10.1159/000277595

25. Gershman B, Dahl DM, Olumi AF, et al. Smaller prostate gland size and older age predict Gleason score upgrading. Urol Oncol 2013;31:1033-7. http://dx.doi.org/10.1016/j.urolonc.2011.11.032. Epub 2011 Dec 28

Correspondence: Dr. Onur Telli, Ankara Training and Research Hospital Ulucanlar Cd. No:89, Altındag/Ankara, Turkey; onurtelli@yahoo.com 